\title{
RESUME PROGRAM INPUT DATA BUKU PRAKTIK BORLAN DELPHI
}

\begin{abstract}
ABSTRAK
Borland Delphi adalah sebuah bahasa pemrograman under windows yang diproduksi oleh Borland, Dengan menggunakan borland delphi ini kita dapat membuat program dari yang sederhana sampai yang berbasis client / server atau jaringan yang berjalan di sistem operasi windows.
\end{abstract}

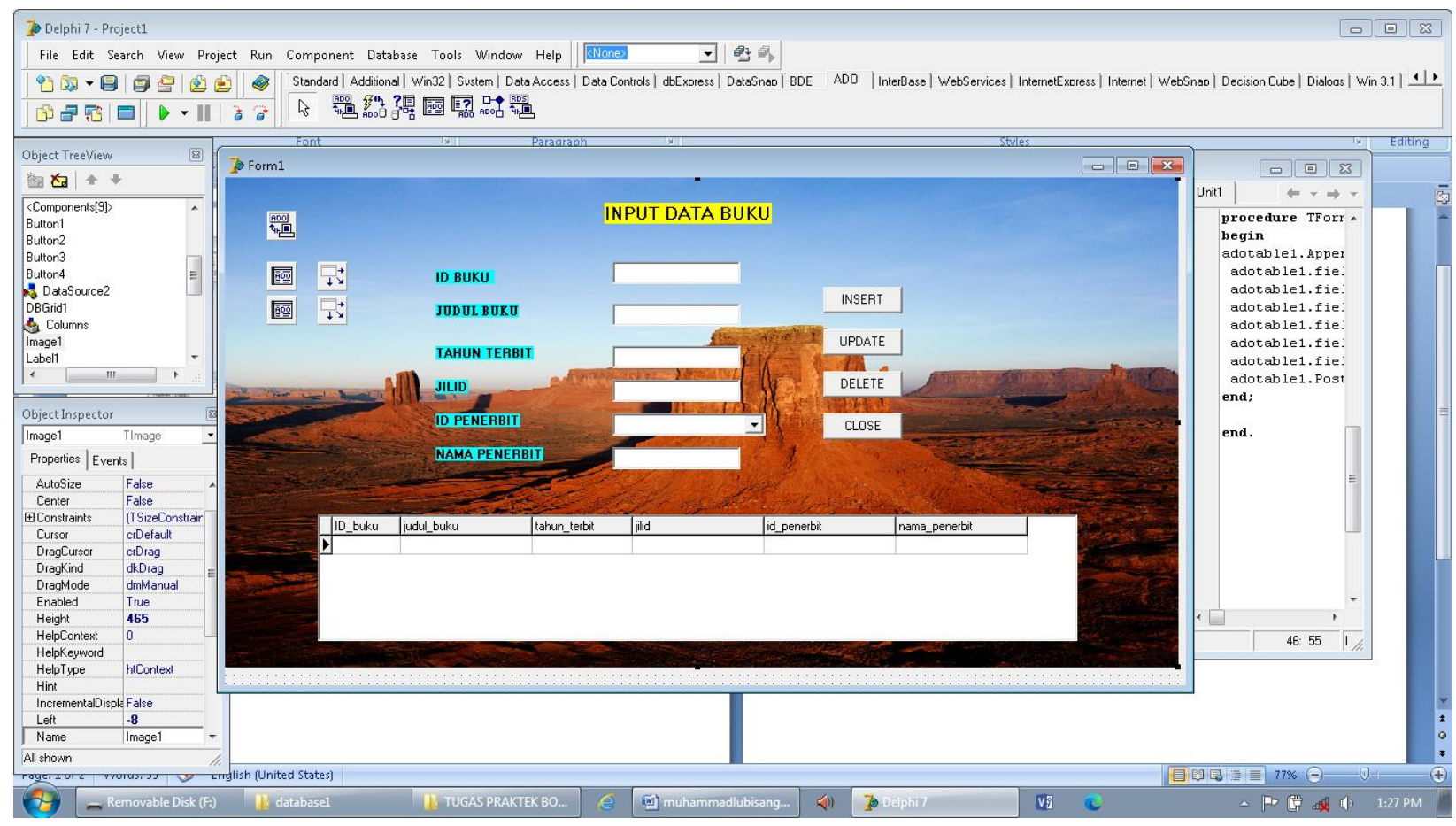




\begin{tabular}{|c|c|}
\hline komponen & Caption \\
\hline Label1 & Input data buku \\
\hline Label2 & Id buku \\
\hline Label3 & Judul buku \\
\hline Label4 & Tahun terbit \\
\hline Label5 & Jilid \\
\hline Label6 & Id penerbit \\
\hline Label7 & Nama pengarang \\
\hline Edit1 & - \\
\hline Edit2 & - \\
\hline Edit3 & - \\
\hline Edit4 & - \\
\hline Edit5 & - \\
\hline ComboBox1 & - \\
\hline Button1 & Insert \\
\hline Button1 & Update \\
\hline Button1 & delete \\
\hline Button1 & close \\
\hline ADOConnection1 & - \\
\hline ADOTable1 & - \\
\hline DataSource 1 & - \\
\hline DataSource2 & - \\
\hline ADOTable2 & - \\
\hline DBGrid1 & - \\
\hline
\end{tabular}

